\title{
A novel approach of mapping landscape aesthetic value and its validation with rural tourism data
}

\author{
ZsuzsANNA LONTAI-SZILÁGYIํ, BogLÁRKA BERTALAN-BALÁZS², BERNADETT ZSIROS ${ }^{1}$, \\ MÁria VASVÁRI ${ }^{2}$, Singh SUdHIR KUMAR ${ }^{3}$, PATEL NILANCHAL", \\ KATALIN MARTONNÉ ERDŐS² and SzILÁRD SZABÓ²
}

\begin{abstract}
Landscape aesthetic research that emerged from the second half of the $20^{\text {th }}$ century has become increasingly appreciated and popular in the last few decades. There are two main reasons for this. On the one hand, the role of landscape aesthetics in land use and environmental planning, management and conservation was recognized. On the other hand, its definition among Cultural Ecosystem Services (CES) has made it clear that landscape aesthetics has a significant impact on human well-being and there is a need to examine it in the concept of Ecosystem Services and, in particular, Cultural Ecosystem Services. The mapping of landscape aesthetics is mostly based on the exclusive evaluation of objective, biophysical landscape factors. The aim of the research was to create the landscape aesthetic map of Hungary with a novel method based on human perception. For this, a questionnaire survey and a GIS approach was used. In order to better understand the role of factors influencing the aesthetic value of the landscape, value maps separately for land cover and elevation that are decisive for the landscape experience were prepared. To validate the results of the maps, and contribute a better understanding of the interrelationship between CES, a certain tourism product was chosen, and the connection between landscape aesthetics and the offer of rural tourism was examined in Hungary and in the Danube Bend priority tourism development area. Our findings show that there is a difference in the results of the objective (GIS based) and subjective (questionnaire based) assessment of landscape aesthetic value with the more important role of elevation in the latter. According to our tourism product-based analysis, which represents a niche approach in its kind, landscape values are higher in the areas with rural accommodation. At the same time, based on the results of the Danube Bend region, it can also be concluded that elevation and land cover together are crucial factors in landscapes considered to be the most valuable in aesthetic terms. The most direct practical application of our research is to orientate further tourism development of the new Danube Bend area designated in 2017.
\end{abstract}

Keywords: landscape value, land cover, questionnaire, weighted average, rural accommodation, validation

\section{Introduction}

From a geographical point of view, natural landscapes, which are uncultivated and dispense with human intervention and cultural landscapes transformed by man to varying degrees can be distinguished. Cultural landscapes have become increasingly dominant due to the intensive landscape-shaping activities driven by human interest, value and emotion (BERÉNYI, I. 2010). According to the generally accepted definition landscape aesthetics is a discipline that deals with the interpretation and evaluation of the enjoyment and pleasure provided by the sight and the observation of natural and man-made land-

\footnotetext{
${ }^{1}$ Corvinus University of Budapest, H-1093 Budapest, Fővám tér 8. E-mails: zsuzsanna.szilagyi@uni-corvinus.hu, bernadettzsiros96@gmail.com

${ }^{2}$ University of Debrecen, H-4032 Debrecen, Egyetem tér 1. E-mails: balazs.boglarka@science.unideb.hu, maria.vasvari@ science.unideb.hu,martonnekati@gmail.com, szabo.szilard@science.unideb.hu

${ }^{3}$ University of Allahabad, Prayagraj 211002, Allahabad, Uttar Pradesh, India, E-mail: sudhirinjnu@gmail.com

${ }^{4}$ Birla Institute of Technology Mesra, Ranchi-835215, Jharkhand, India, E-mail: nilanchal.patel@gmail.com
} 
scapes (Csemez, A. 1996; Kumar, P. 2010; Swaffield, S.R. and McWilliam, W.J. 2013). The aesthetic value of the landscape as a secondary natural resource for the economy (RÉTVÁRI, L. 1986) is becoming more appreciated and increasingly emphasized. The preservation of the traditional landscape and the development of its characteristic features are important areas of landscape and environmental planning, the protection of monuments and nature that build on cognition and emotional attachment (SAUNDERS, F.P. 2012; Milcu, A.I. et al. 2013; SwAFField, S.R. and McWilliam, W.J. 2013; ANDERsson, E. et al. 2014; LANGEMEYer, J. et al. 2018; TRibot, A.S. et al. 2018), as well as leisure and tourism developments (Lóczy, D. 2002; KolláNYI, L. et al. 2012).

Based on the literature, landscape aesthetics research has two, ideally complementary approaches, an objectivist or physical, that is the transmitter-side (the indirect assessment of landscape aesthetics) and a subjectivist or psychological, that is the receiver-side (the direct assessment of landscape aesthetics). Transmitter-side assessments capture the value of the nature of landscapes, determined by their biophysical features that trigger the aesthetic response (Lothian, A. 1999; FrY, G. et al. 2009; FranK, S. et al. 2013; MüDERrisogLu, H. and Gultekin, P.G. 2013; Tribot, A.-S. et al. 2018). The receiver-side approach describes landscapes with the psychological explanation of emotions, the socio-cultural background and through human perception and preferences (DANIEL, T.C. et al. 2012).

In 2005 the Millennium Ecosystem Assessment (MEA) defined landscape aesthetics and recreation (including tourism), along with other benefits (spiritual, educational etc.) obtained from ecological communities and their environment, as Cultural Ecosystem Services (CES). CES are important not only because they contribute to human well-being (Oteros-Rozas, E. et al. 2018), but presumably increasingly determine it (Guo, Z. et al. 2010). As with the aesthetic value of landscapes (LEE, S. et al. 2011; ТRівот, A.-S. et al. 2018), it is especially true for recreation and tourism that they contribute to the enjoyment (VAllés-Planells, M. et al. 2014), the health and the personal and social fulfilment of people. Despite their obvious significance and being at the forefront of research on ecosystem services, numerous studies have pointed out that the standardized assessment and spatially explicit representation of CES is rather difficult due to their non-material, intangible and often subjective nature (Plieninger, T. et al. 2013; ANDERsson, E. et al. 2014; Casado-Arzuaga, I. et al. 2014; SMith, M. and RAM, Y. 2016; UngARo, F. et al 2016; LANGEMEYER, J. et al. 2018).

Landscape reflecting the specific synthesis of the economic, cultural and aesthetic activities of society in addition to ecological attributes (Michalkó, G. 2008) is a key element for tourism. On the one hand, landscapes mean the environment of tourism with which it interacts closely. The growing demand for activities in nature (Michalкó, G. 2008) typically involves the construction of infrastructure that can cause significant changes in the environment, thereby worsening the aesthetic value of the landscape or causing irreversible damage to nature. Although the extent of the impact of recreational and tourism activities on the natural and built environment is relatively low compared to the impacts of most sectors (e.g. agriculture and industry), the approach that takes into account the context of nature and tourism related interventions and activities is becoming more and more important (DÁvid, L. and SzILÁGYI, Zs. 2008). Furthermore, as the aesthetic value of landscapes is closely linked to their tourism potential, its evaluation is a significant aspect of tourism planning to underpin sustainable development and to prevent and deal with the negative effects of tourism (Lóczy, D. 2002). On the other hand, landscapes are integral parts of the attractions for many recreational activities (e.g. hiking, horse riding, skiing). Thus, the features of landscapes, including their beauty, aesthetics and biophysical characteristics, are key components of tourism experience (HEALY, R.G. 1994; TodD, C. 2009), while it can also play a decisive role in the choice of destination (Macagno, G. et al. 2010) and the intention of return (BALOGLU, S. et al. 2004). 
Many researchers have described that waterfront and mountainous areas, especially if they occur together offer one of the most attractive tourism supplies (SOMOGYI, S. 1987; Martonné Erdós, K. 1990; Szalai, K. and Szilágyi, Zs. 2007; Aubert, A. 2008). Based on the collection of CARNEIRo, M. et al. (2015), studies on consumer preferences have also shown that tourists' landscape preferences can be influenced by many factors, which are either due to the socio-demographic features of tourists, e.g. age (MúGICA, M. and De Lucio, J.V. 1996; Pérez, J.G. 2002), type of settlement where the individual's grown up and agricultural experiences (ArNBERger, A. and EDER, R. 2011) or to the characteristics of the travel (e.g. season of the year and weather conditions (Pérez, J.G. 2002), time spent at the destination (Múgica, M. and De Lucio, J.V. 1996) and activities in the area (MúGICA, M. and De Lucio, J.V. 1996; Rogge, E. et al. 2007; Surová, D. and Pinto Correia, T. 2008; Aranzabal, I. et al. 2009). The appreciation of consumer decisions nowadays also allows for studies that try to express the aesthetics of landscapes in monetary terms (CsorbA, P. et al. 2018), which is the most possible in places where tourists mainly choose the destination to have landscape experience. Landscape elements often play an important role in shaping the image of a destination (Lew, A.A. 1991; Puczkó, L. and RÁtz, T. 2011), which is also proved by the fact that these are one of the most frequently studied factors in international and Hungarian tourism image research (Gallarza, G.M. et al. 2002; Spiegler, P. 2011; SzAlaI, K. and HineK, M. 2013). In addition, aesthetic landscapes are resources that can be important factors in pricing and sales of tourism services. WANG, Y. et al. (2008) emphasize that the decrease in the landscape aesthetic value of natural destinations is associated with their economic depreciation. That is, a deeper understanding of the complex relationship between landscape aesthetics and tourism is essential not only within the CES framework but also for the planning and the sustainable operation and development of the tourism sector (SмITH, M. and RAM, Y. 2016).
Studies on the aesthetic value of landscapes are in most cases based only on the evaluation and mapping of objective landscape factors. At the same time, the assessment of landscape aesthetics cannot be decoupled from its primary beneficiary, i.e. the people. As the perception of landscape beauty varies from person to person, and they depend heavily on circumstances, age and culture (KolláNYI, L. et al. 2012), these inquiries cannot ignore personal opinions. The multidimensional relationship between landscape aesthetics and tourism is also explored empirically by various studies (Adamowicz, W.L. et al. 2011; Willis, C. 2015; Sмiтh, M. and RAM, Y. 2016). However, still there is a shortage in larger area (like countries) or tourism product type studies, which is also due to the need for a multidisciplinary approach.

The primary aim of our study was to map the landscape aesthetic value of Hungary using the Geographical Information System (GIS) approach through the perceived value of different landscape factors. This perspective has been less pronounced so far whereupon still there is a lack of the GIS-based landscape aesthetic maps reflecting visitors' views. Among the natural and artificial landscape features that can be considered objective, elevation and land cover play a key role in determining landscape experience (Szalai, K. and SzILÁGYI, Zs. 2007). Therefore, the focus was on these landscape factors during our examination and land cover and elevation value maps were also prepared. Our further goal was to validate the results with the offer of rural tourism, i.e. the number of bed-places in rural accommodation. Our main question was whether the areas (settlements) where there is a rural accommodation can be characterized by greater landscape aesthetics. For the study, rural tourism was chosen, a type of tourism product for which landscape has a rather passive and emotional role, while its aesthetic value is decisive and even more important (Lontai-SzILÁgyi, Zs. et al. 2017).

Prior research in Hungary revealed that the offer of the most successful rural accommodation service providers is typically 
based on the proximity of thermal baths, waterfront areas and unique natural environment, which undermines the role of traditional rural attractions (e.g. rural lifestyle, the atmosphere of the place, unique settlement image) (МichaLкó, G. 2012). Further considerations were the relatively good territorial distribution of rural accommodation within the country and the availability of exact, municipal-level statistical data. In addition to Hungary, we have chosen the Danube Bend region as a study area, which is a traditional and popular destination for a variety of leisure and tourism activities (e.g. active tourism, cultural tourism, rural tourism, river cruise tourism). The Danube Bend region located in the immediate vicinity of the capital has an outstanding landscape and natural environment, which is a factor that multiplies the imposing cultural and historical values of the area. Our choice was also made for the Danube Bend region, because the more prominent role of landscape in rural tourism is even more important in metropolitan areas (LoNTAI-SzILÁGYI, Zs. et al. 2017). The examination of the Danube Bend region is also justified and current because a government decree (Government Decree No 1550/2017 (VIII.18.)) re-defined it as a priority tourism development area, in which our novel research can contribute to further tourism development policy decisions.

\section{Study areas}

Our study areas were Hungary and the Danube Bend region.

Hungary, with its $93,023 \mathrm{~km}^{2}$ is located in the Carpathian Basin between the Alps, the Carpathians and the Dinarides, in the south-eastern part of Central Europe (GÁbRIs, Gy. et al. 2018; Kocsis, K. 2018). It is predominantly a lowland country, as 82.4 per cent of its territory is less than $200 \mathrm{~m}$ above sea level and only 0.6 per cent is above $500 \mathrm{~m}$ (Kocsis, K. 2018). The highest point of the country is the Kékes (1014 m) in Mátra Mountains. The proportion of mountains (traditionally including also some territories between 300 and $500 \mathrm{~m}$ above sea level) is 2.1 per cent, while hills represent 15.5 per cent (GÁBris, Gy. et al. 2018).

The country belongs to the Danube catchment area. Hungary's water network can be regarded as two-axis by the Danube and the Tisza. Lakes, among which Lake Balaton $\left(596 \mathrm{~km}^{2}\right)$ is the largest, are just over 1 per cent of the country's territory (VARGA, Gy. et al. 2018). Due to its favourable natural conditions, 79.7 per cent of the country's area is cultivated $(46.6 \%$ of arable land, $20.8 \%$ of forest, $8.4 \%$ of grassland). It refers to the rich natural values of Hungary, that about 22.24 per cent $\left(20,684.4 \mathrm{~km}^{2}\right)$ of its territory is under protection (SzILAssi, P. et al. 2017). There are 10 national parks, with a total of 5.2 per cent of the country's area (TARDY, J. et al. 2018).

In Hungary, tourism is a dominant sector of the economy, which has strategic importance. According to the data of the Hungarian Central Statistical Office (HCSO), in 2016, regarding direct and indirect effects the value added by tourism was 10.7 per cent of the national economy, and the sector contributed 13.2 per cent to the employment (HCSO, 2019). Due to its outstanding medicinal water supply worldwide, health tourism is Hungary's most important tourism product. In addition, cultural tourism (including wine and gastronomy tourism and event tourism), active tourism and Meetings, Incentives, Conferences and Exhibitions (MICE) tourism have to be highlighted in the country's tourism offer (Puczkó, L. and Rátz, T. 2006). One third of the country's total tourism turnover is realized by Budapest. In Hungary, the development of tourism is based on destinations, as a result of which, from 2016 onwards, priority tourism development areas with outstanding importance from the point of view of foreign and domestic tourism are being determined. Priority development areas so far identified are Lake Balaton; Sopron-Fertő; Tokaj, Upper Tisza and Nyírség; the Danube Bend, Debrecen, Hajdúszoboszló, Hortobágy and Lake Tisza (Hungarian Tourism Agency, 2017). 
There are 3,154 municipalities in the country, some 57 per cent of which are villages with less than 1,000 inhabitants (Kocsis, K. 2018). In Hungary, the roots of rural tourism date back to the 1930s (Rени́к, G. 2011), and its role in supporting livelihood and earnings has played a key role in its development and spread. According to the HCSO, in 2017, rural accommodation accounted for 5.4 per cent of total number of bed-places and 1.4 per cent of total guest nights in Hungary. Although since 2010, the capacity of rural accommodation has been decreased by 32 per cent building on the country's natural and cultural assets and focusing on quality services there can be potential in its development. Rural tourism is primarily popular among domestic residents (86.5\% of guest nights in 2017 were due to domestic guests). Based on the number of guest nights, rural tourism is concentrated primarily in Northern Hungary and the Central and the Western Transdanubia regions.

The Danube Bend region is situated North of Budapest. In order to validate our landscape value maps for an area of outstanding leisure and tourist interest, the Danube Bend region was also selected as a study area (Figure 1). The Danube Bend traditionally considered to be the number one excursion and recreation area of Budapest was designated as a priority tourism development area with 70 settlements by Government Decree No 1550/2017 (VIII.18.). This study area with its $1,746 \mathrm{~km}^{2}$ occupies 1.9 per cent of Hungary's territory.

In the names of tourist destinations, attractive-sounding geographical elements are used in many cases, which also refer to the characteristics and specific features of their tourism offer (Kavaratzis, M. and Ashworth, G. 2005; Sмiтh, M. et al. 2018). As its name, which turned into one with leisure and tourism, also suggests, the Danube Bend is characterized by the beautiful valley of the Danube, which forms a sharp curve as breaks through the Visegrad Strait (Photo 1). The elevation of the region, including lowlands, river valleys, hills, basins and volcanic and karst mountains, is diverse and has a significant relative relief in comparison with other parts of the country. Lowlands account for only about half of the national value $(45.4 \%)$, while the proportion of hills

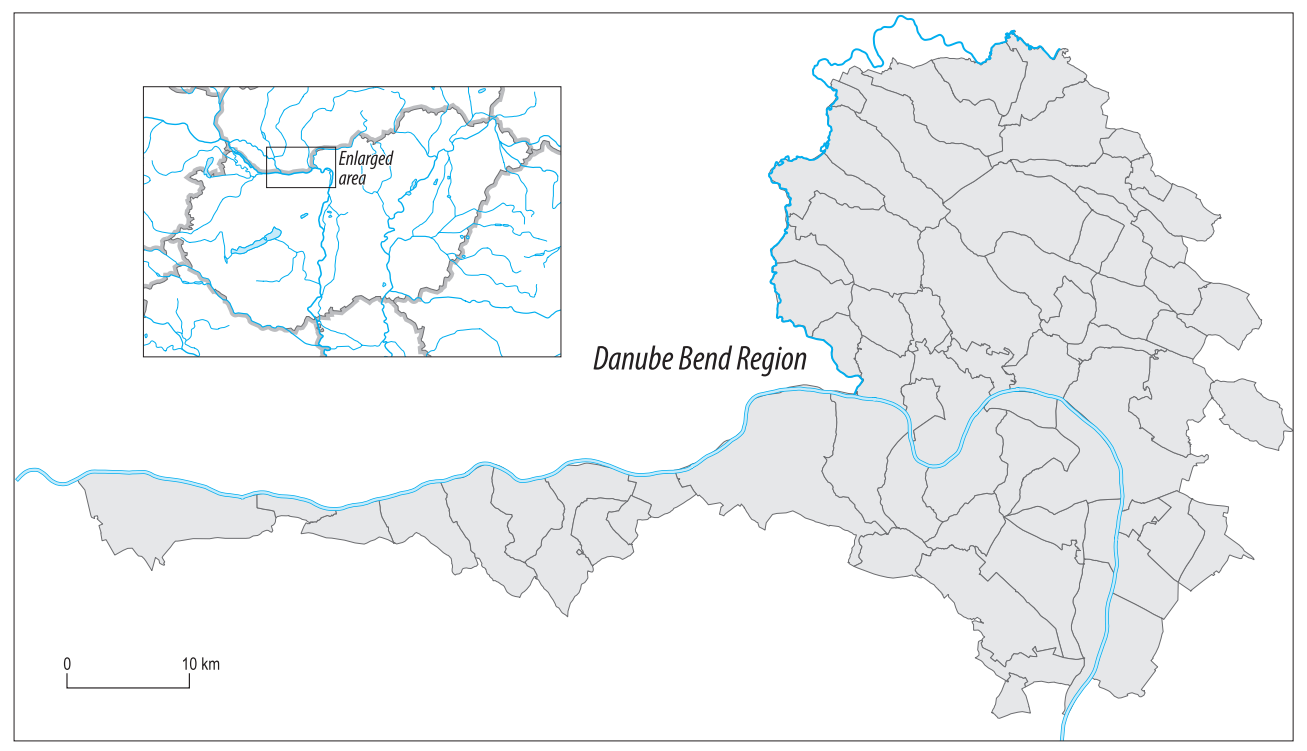

Fig. 1. Geographical position of the Danube Bend region inside Hungary 


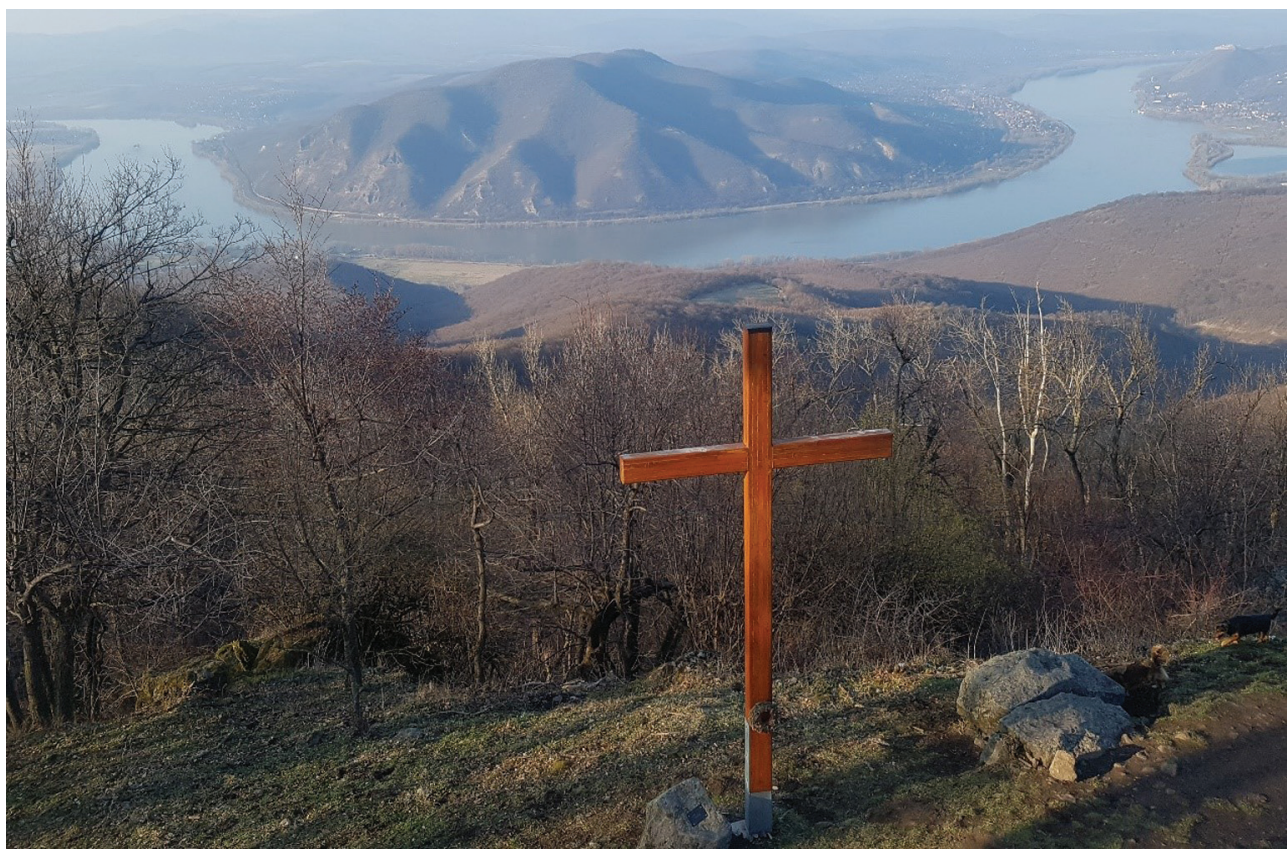

Photo 1. Panorama of the Danube Bend from the Prédikálószék (Photo by LonTaI-SziLágYI, Zs.)

(48.1\%) and mountains (6.6\%) is significantly higher than the national figure.

Beside the Danube River, its tributaries and streams, there are several smaller, but attractive and valuable water bodies in the region. The land cover differs from the national average, forests have 43 per cent, agricultural areas 26 per cent in the total area, while the proportion of grasslands is more or less the same. Most of the area coincides with the Danube-Ipoly National Park (founded in 1997 and covers a total of $603.14 \mathrm{~km}^{2}$ ), which is protected principally due to its high forest cover, special rock formations, flora and fauna and cultural history.

Beyond its location close to Budapest, the role of the Danube Bend in recreation and tourism, is also due to the diverse tourism supply of the area (Figure 2), which is largely based directly or indirectly on landscape features and aesthetics. The panorama provided by the forest-covered mountains and the river is the cornerstone of the image of the region.

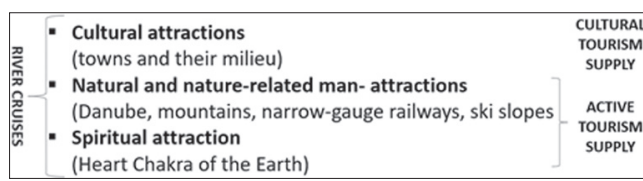

Fig. 2. Current experienced based tourism supply of the Danube Bend priority tourism development area

(Based on Hungarian Tourism Agency, 2017)

Settlements with close-to-nature landscapes, especially with waterfront and mountainous experiences and rural milieu, are attractive places for rural tourism (LoNTAI-SzILÁGYI, Zs. et al. 2017). Rural tourism is not a typical metropolitan tourism product, so it is not a dominant supply element in the Danube Bend either. At the same time, some features and trends predict the appreciation of nature-close trips in rural environments in metropolitan areas. Nowadays, the rushing and bustling population of urban areas with environmental nuisances is eager to recreate in rural milieu 
(Kulcsár, N. 2013; Cofas, E. 2014). In addition, time-consuming and productive use of leisure time is becoming more and more important in the accelerated life, forcing the townspeople to relax as close to their everyday life as possible (PAGE, S. and Connel, J. 2010). As a consequence of suburbanisation, it is a common phenomenon that those who are unsatisfied with urban life start a new one in the nearby "rural idyll" (DövéNYI, Z. and Kovács, Z. 1999; ВаJмócy, P. 2014). Building a rural guesthouse in the neighbourhood of large cities and providing quality services around it, based on continuous demand, has now become an absolutely viable business model (Lontai-SzILÁGyi, Zs. et al. 2017).

Overall, the Danube Bend was considered a suitable study area because

- it can be characterized with varied elevation and a relatively large relative relief;

- it is a traditional, popular and regarding its tourism supply a complex and not a one profil-leisure and tourism destination, which has a prominent role of landscape in tourism;
- from a tourism policy point of view, it is a currently formed area, so our research results may have an impact on further land use and tourism development decisions;

- given the large potential demand and its characteristics and the modernization of rural tourism during which the landscape plays an increasingly important role, the relevance of rural tourism research in the Danube Bend region can be supported.

\section{Methods and data}

\section{Questionnaire to assess landscape values}

A questionnaire was elaborated to assess landscape value. As landscape value have relevant dependency of people's thinking about it, we aimed to get information about the personal opinions. We applied a 6-grade Likert scale with ranking of different subunits of general land cover types (Table 1) and elevation (plains, hills or mountains). Be-

Table 1. Land cover classes of the questionnaire

\begin{tabular}{l|l}
\hline Land cover type & \multicolumn{1}{c}{ Land cover subtype } \\
\hline \multirow{5}{*}{ Grasslands } & Pastures with animal grazing and anthropogenic activities \\
& Pastures with smaller arable land patches, forest belts, marshes or wetlands \\
& Natural grasslands without trees and bushes \\
& Natural grasslands with trees and bushes \\
& Grasslands with shrubs and sparse trees \\
& Shrubby, stony grasslands \\
\hline \multirow{5}{*}{ Forests } & Natural deciduous forests \\
& Deciduous forest plantations \\
& Nature close pinewoods \\
& Pinewood plantations \\
& Mixed (deciduous forests and pinewoods) forests \\
& Spontaneous young forests with shrubs \\
\hline \multirow{5}{*}{ Water features } & Marshlands \\
& Rivers \\
& Sandy riverbanks with some vegetation \\
& Channels \\
& Natural lakes \\
& Fish ponds, mining lakes or reservoirs \\
\hline \multirow{5}{*}{ Agricultural areas } & Arable lands and grasslands with patches of forests or water \\
& Vineyards or orchards with patches of grasslands, forests or water \\
& Intensive agricultural areas with large parcels \\
& Agricultural areas with small parcels \\
& Greenhouses \\
& Mixed agricultural areas (small patches of arable lands, orchards, grasslands, gardens) \\
\hline
\end{tabular}


sides, we also had questions about the gender, age, education level, employment status, and city of respondents as background/demographic variables.

Sampling was carried out with the usage of Google Docs and after testing the questionnaire, they were distributed through the internet: sharing on Facebook, Twitter and LinkedIn. We had 332 respondents and the sample represented the population of $\leq$ 50 years $(36 \%$ were under 25 , and $56 \%$ between 25 and 50 years), mostly graduated in high schools (23\%) or had BSc/MSc diploma $(68 \%)$, ratio of males and females was almost the same (i.e. $49.8-50.2 \%$, respectively).

\section{Corine Land Cover 50}

We applied the Corine Land Cover 50 (CLC50) database as land cover input data in our model. Although CLC50 was developed using 1998-1999 SPOT-4 satellite images, its thematic accuracy is 90 per cent; furthermore, the minimum mapping unit was 4 ha (BüTtNer, Gy. et al. 2002). Related to the recently released CLC2018, CLC50 had 79 land cover categories, which fitted better to the categories applied in the questionnaire. Thus, accepting the changes of the last 20 years, considering the change layers of recent of newer CLC editions (usually the changes are not relevant), generally, CLC50 was able to reflect the main features of land cover even in 2019.

\section{$E U-D E M$}

EU-DEM is a digital surface model, which is developed as a weighted averaging data fusion approach of SRTM and ASTER GDEM datasets (Szabó, G. et al. 2015). As both the SRTM and ASTER GDEM, EU-DEM is also a freely available dataset with geometric resolution of $25 \mathrm{~m}$ (EU-DEM Metadata). We used the EU-DEM v1.1. Reported model error (JózsA, E. et al. 2014) did not influence our evaluation regarding the classes of elevation.

\section{Rural tourism data}

According to the current government decree on the conditions of rural accommodation services, villages below 5,000 inhabitants and rural settlements below 100 inhabitants $/ \mathrm{km}^{2}$ are included in the statistics, excluding the settlements and health resorts of Lake Balaton (Government Decree No 239/2009 [20 October]). Data on the number of bed-places in rural accommodation were collected from the HCSO's information database for Hungary and the relevant municipalities of the Danube Bend region. From the data reported annually we used the ones currently available for 2017.5

\section{Landscape value indices}

Weighted average was calculated from the answers of the questionnaires (Eq. 1)

$$
\overline{x_{w}}=\frac{\sum_{i=1}^{n} f_{i} \cdot x_{i}}{\sum_{i=1}^{n} f_{i}},
$$

where $x_{i}$ is the value of a given question in the questionnaire; $f_{i}$ is the number of respondents.

Then the land use/land cover classes of the questionnaire and the CLC50 map were corresponded to each other. As a next step, the land cover map was intersected with the administrative borders of the settlements. This step required an additional step, the calculation of a single landscape value for the settlements: we applied weighted averages using the area as a weighting factor (Eq. 2). Thus, we gained the administrative border-based map of the landscape values considering the land cover (LCV).

$$
\overline{y_{w}}=\frac{\sum_{i=1}^{n} a_{i} \cdot \bar{x}_{w j}}{\sum_{i=1}^{n} a_{i}},
$$

where $x_{w j}$ is the value of the weighted average of land cover classes of settlement $j$, and $a_{i}$ is the area of land cover for land cover class $i$.

\footnotetext{
${ }^{5}$ It should be noted that the HCSO due to insufficient number of element numbers occasionally classifies the statistics of the accommodation sector including rural accommodation units as sensitive and does not report it.
} 
Topographic categories were classified using the EU-DEM dataset according to Table 2. Next, the weights of plains, hills and mountains were determined by the number of respondents. Finally, Elevation Value (TopoV) was calculated as the area-weighted average of the elevation categories' assigned values (Table 2).

\section{Table 2. Calculated weights of the elevation}

\begin{tabular}{l|l|c}
\hline $\begin{array}{l}\text { Terrain } \\
\text { height, } \\
\text { m a.s.1. }\end{array}$ & Category & $\begin{array}{c}\text { Weighted average } \\
\text { based on the } \\
\text { questionnaires }\end{array}$ \\
\hline $0-200$ & Plain & 1.421 \\
$200-500$ & Hill & 2.116 \\
$500<$ & Mountain & 2.463 \\
\hline
\end{tabular}

Landscape Aesthetic Value (LAV) is the simple sum of the Land Cover (LCV) and Elevation Values (TopoV) (Figure 3).

\section{Statistical analysis}

We applied hypothesis testing to reveal whether landscape value was significantly larger if rural accommodation possibilities were present on a settlement. $H_{0}$ was that variances were equal for settlement groups where rural accommodations present and those where there was not any accommodation; $H_{1}$ was that variances were different. According to the Shapiro-Wilk test, landscape values had normal distribution for settlements of the Danube Bend region. However, as Levene-test indicated the violation of variance homogeneity, we applied the robust Yuen's test with 20 per cent trimming option (FIELD, A. et al. 2012). Beside significance value (i.e. $p$ ), we also determined the effect size $(\xi)$, which is a standardized measure of the magnitude of the difference between two groups (i.e. country level data and Danube Bend region; settlements where rural accommodations exist or not (CoHEN, J. 1992; Field, A. et al. 2012).

We conducted correlation analysis between LCV and TopoV indices to reveal whether land cover and elevation had a strong relationship on the level of settlements. According to the violation of normal distribution, we applied the Spearman correlation coefficient (КАвакоFF, R.I. 2011). Hypothesis testing and correlation analysis was conducted with R 3.5.2 (R Core Team, 2019) with the walrus (Love, J. and MAIR, P. 2017) package.

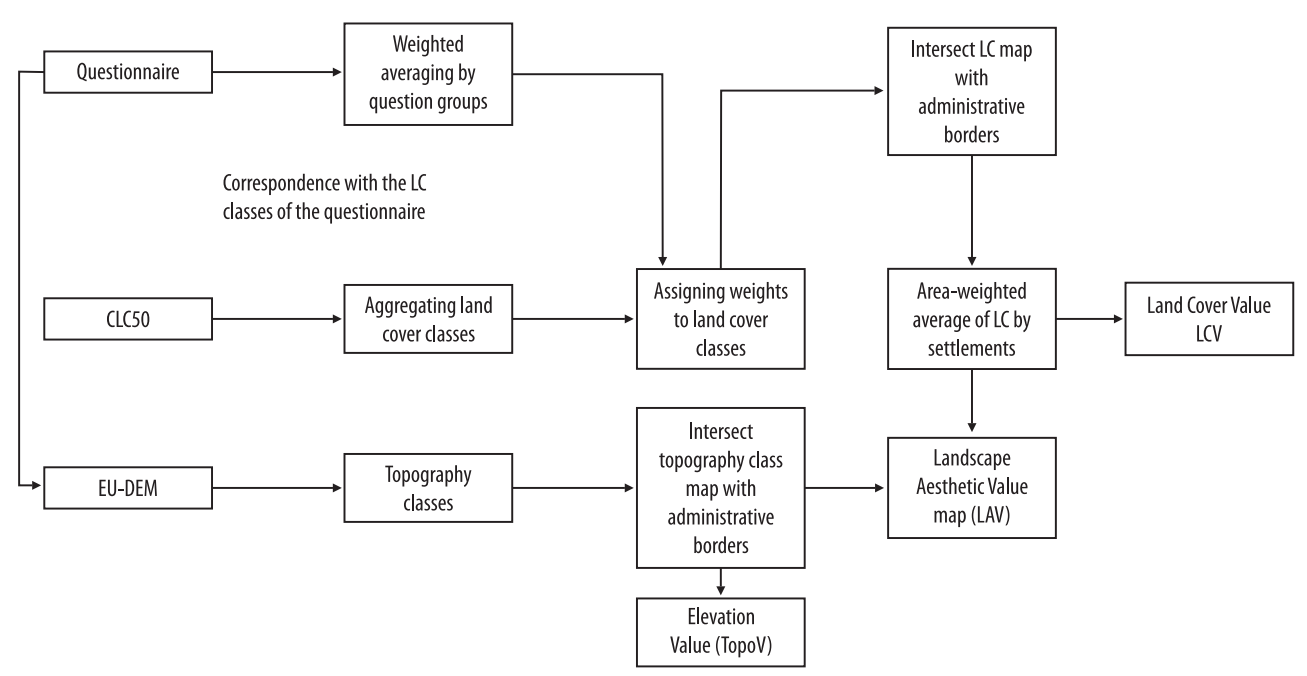

Fig. 3. Workflow of the calculation of different landscape values 


\section{Results}

\section{Landscape values}

Landscape values had different scales regarding the possible minimums and maximums (for LCV: 0-6, for TopoV: 0-3, and for LAV: 0-9); therefore, there were differences in the descriptive statistics of landscape value indices (Table 3). As most of the area

Table 3. Descriptive statistics of landscape value indices on country level

\begin{tabular}{l|r|r|r}
\hline \multicolumn{1}{c|}{ Descriptive statistics } & LCV & TopoV & LAV \\
\hline Min & 0.00 & 0.00 & 1.42 \\
Max & 5.97 & 2.45 & 7.41 \\
Mean & 3.22 & 1.60 & 4.82 \\
Standard deviation & 0.56 & 0.25 & 0.68 \\
Lower quartile & 2.86 & 1.40 & 4.33 \\
Median & 3.08 & 1.42 & 4.65 \\
Upper quartile & 3.50 & 1.76 & 5.21 \\
Coefficient of variations & 17.54 & 15.78 & 14.21 \\
\hline
\end{tabular}

of the country had lower values, both mean and medians were rather low related the possible maximums. Considering the land cover (LCV), lower quartile and median were close, while upper quartile had larger value; however, even upper quartile was close to the half of the possible maximum (Figure 4). TopoV resulted in a map where lower quartile was close to the median, and median was lower than the mean (Figure 5). As large areas belong to plains, and respondents preferred hilly and mountainous landscapes, these values were rather low. LAV almost reached at least in case of one settlement the possible maximum (7.41 at Bükkszentkereszt), and the upper quartile was at 65 per cent of the possible maximum (Figure 6).

Correlation analysis revealed that there was only a weak connection between the TopoV and LCV indices $(r=0.32 ; p<0.001)$; therefore, it was not obvious that the most preferred land cover units coincided with the mountains, which was ranked the highest among the respondents.

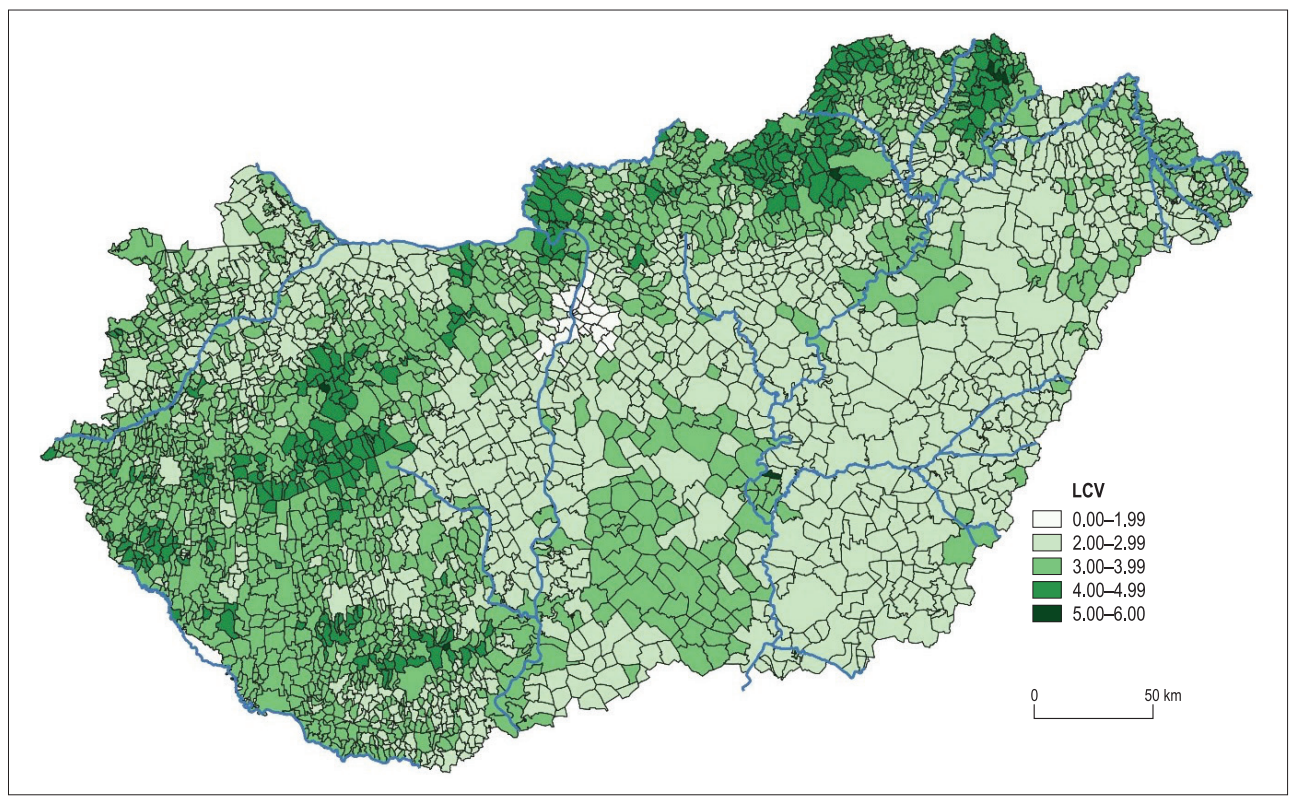

Fig. 4. Land Cover Value (LCV) map of Hungary 


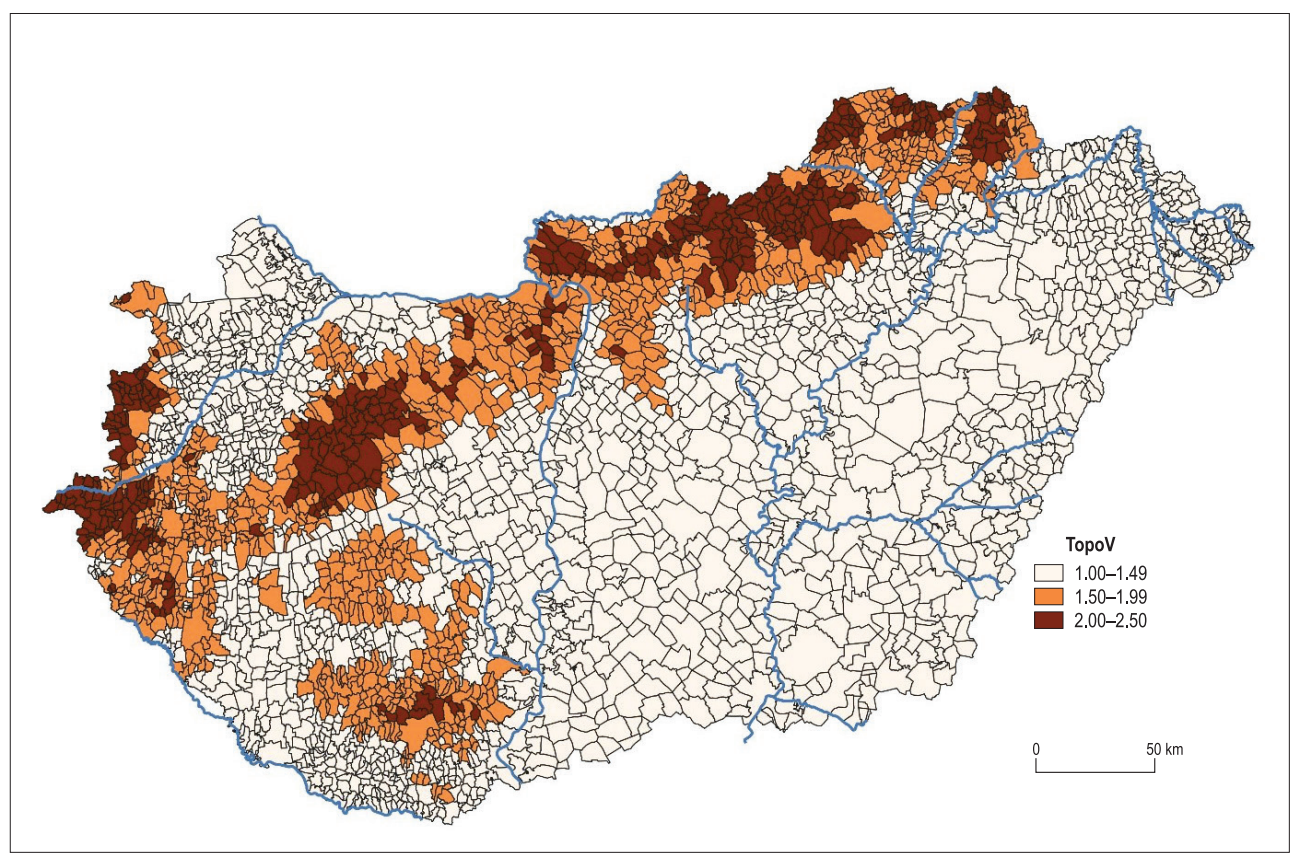

Fig. 5. Elevation Value (TopoV) map of Hungary

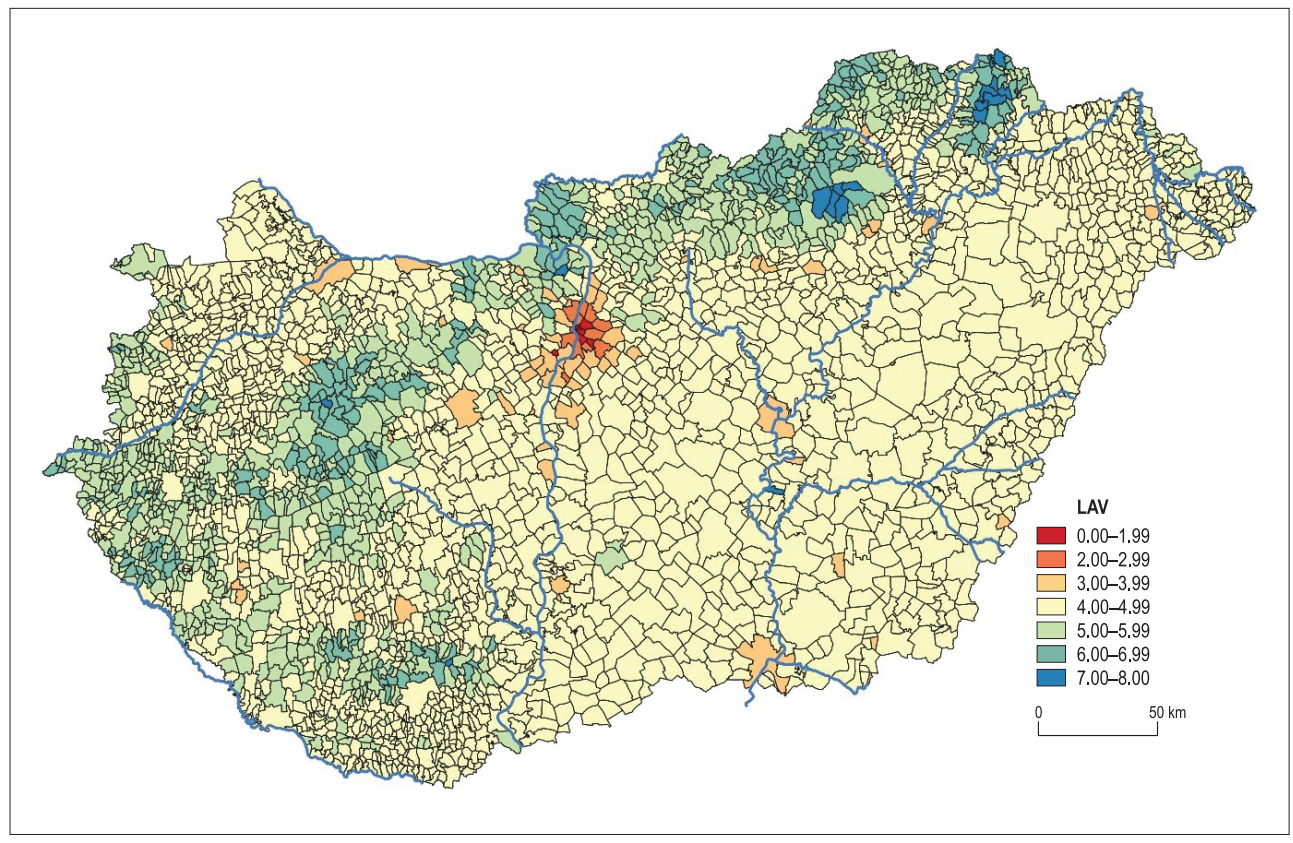

Fig. 6. Landscape Aesthetic Value (LAV) map of Hungary 
Landscape values of the Danube Bend region

As the Danube Bend region is a mountainous environment being preferred by respondents of the survey, it was reflected in landscape values, too (Figure 7). All values were significantly higher $(p<0.001)$ in case of Danube Bend region related to the country level. Differences between the median were about 10 per cent higher for the Danube Bend region (LCV: 0.7; TopoV: 0.3; LAV: 0.7). Differences were significant for all landscape values; furthermore, effect sizes indicated medium effect for TopoV and LCV and large effect for LAV (Table 4); all medians were higher in case of the Danube Bend region.

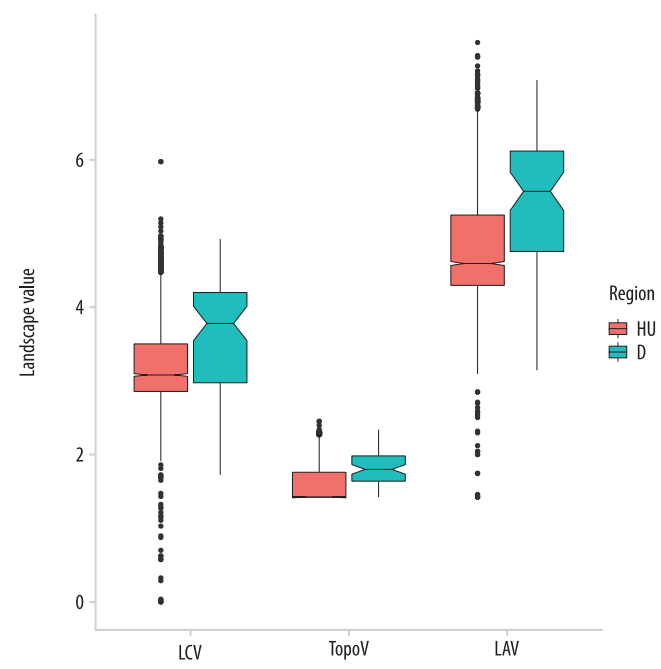

Fig. 7. Landscape values of Hungary (HU) and the Danube Bend region (D). - LCV = Land Cover Value; TopoV = Elevation Value; LAV = Landscape Aesthetic Value. Boxplots represent median, interquartile range and 1.5 times interquartile range; notches display the standard error.

\section{Statistical validation of landscape values}

Comparison of landscape values by rural accommodation possibilities revealed significant differences $(p<0.05)$ both in case of involving all settlements of Hungary and in case of settlements of the Danube Bend region (Figure 8 and 9). Each comparison resulted in higher values of settlements having rural accommodation; i.e. these settlements had larger scores for all the three indices, the only difference was the magnitude. Effect size $(\xi)$ indicated slighter differences for comparisons of Hungary related to the Danube Bend region. TopoV index's effect size was small, showing almost negligible rele-

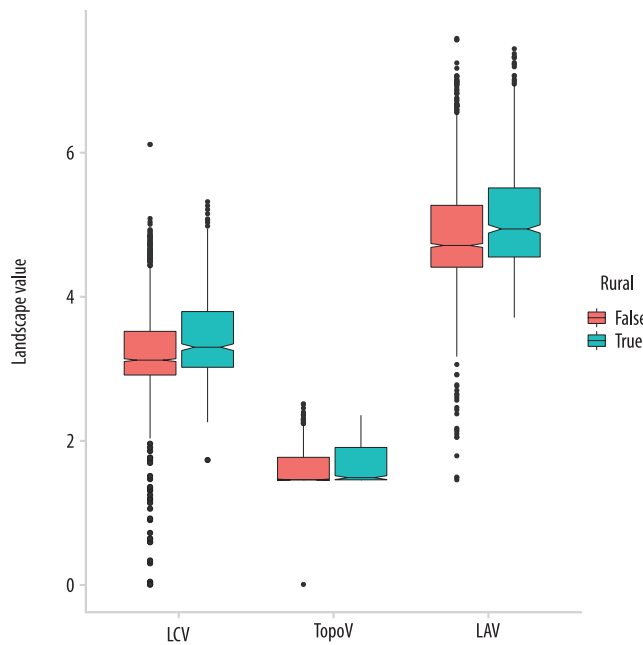

Fig. 8. Landscape values of Hungary by rural accommodation possibility. - LCV = Land Cover Value; TopoV = Elevation Value; LAV = Landscape Aesthetic Value; True = rural settlement with available rooms; False $=$ rural settlement without available rooms Boxplots represent median, interquartile range and 1.5 times interquartile range; notches display the standard error.

Table 4. Robust Independent Samples T-Test of landscape values between Hungary and the Danube Bend region

\begin{tabular}{l|c|c|c|c|c}
\hline Landscape value & Test & $\mathrm{t}$ & $\mathrm{df}$ & $\mathrm{p}$ & $\xi$ \\
\hline LCV & & 5.03 & 42.6 & & 0.496 \\
TopoV & Yuen's test & 4.02 & 42.9 & $<0.001$ & 0.383 \\
LAV & & 5.33 & 42.8 & & 0.526 \\
\hline
\end{tabular}




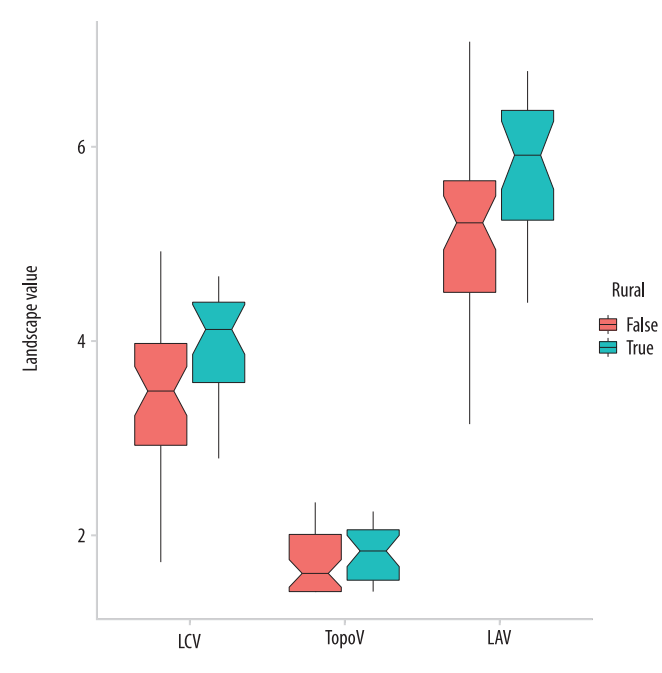

Fig. 9. Landscape values of the Danube Bend region by rural accommodation possibility. - LCV, TopoV, LAV, True, False, boxplots and notches: for explanation see Fig. 8.

vance and the other two indices (LCV and LAV) had a bit larger but still slight effect (Table 5). However, in case of the Danube Bend region, the effect of rural accommodation had low effect for TopoV, but its magnitude was the double related to country scale. The effect sizes were medium level for LCV and LAV (Table 6).

\section{Discussion}

Whether or not within framework of CES, the aesthetic evaluation and mapping of the landscape has already been attempted by many researchers using a variety of methods. The followers of the transmitter-side approach based on the biophysical parameters of landscapes ultimately decide for themselves which landscapes are considered aesthetic and which are not, and in most cases the results are represented on a map. Researchers of the receiver-side approach, based on human perception, examine the aesthetic value of landscapes, most often using questionnaire surveys or the evaluation of photos showing different landscapes. However, presenting results on a map is much less characteristic of these kinds of research. Strengthening the adaptation of receiver-side approach, SwAFFIELD, S.R. and McWilliam, W.J. (2013) argued that instead of 'aesthetic value' the term 'aesthetic experience' is more meaningful as it expresses the pivotal role of individual and cultural factors in considerations of aesthetic landscape. In human perception based research, a wider range of people can be included in the assessment, but subjectivity is also increasing.

The aesthetic value of landscapes varies from person to person (KNUDSEN, D.C. et al. 1995)

Table 5. Robust Independent Samples T-Test of landscape values in cases when rural accommodation is present or not - Hungary

\begin{tabular}{l|c|c|c|c|c}
\hline Landscape value & Test & $\mathrm{t}$ & $\mathrm{df}$ & $\mathrm{p}$ & $\xi$ \\
\hline LCV & & 7.09 & 580 & & 0.234 \\
TopoV & Yuen's test & 3.67 & 542 & $<0.001$ & 0.131 \\
LAV & & 6.76 & 592 & & 0.230 \\
\hline
\end{tabular}

Table 6. Robust Independent Samples T-Test of landscape values in cases when rural accommodation is present or not - the Danube Bend region

\begin{tabular}{l|c|c|c|c|c}
\hline Landscape value & Test & $\mathrm{t}$ & $\mathrm{df}$ & $\mathrm{p}$ & $\xi$ \\
\hline LCV & & 3.43 & 38.8 & 0.001 & 0.495 \\
TopoV & Yuen's test & 1.30 & 34.2 & 0.202 & 0.230 \\
LAV & & 3.33 & 35.0 & 0.002 & 0.497 \\
\hline
\end{tabular}


and depends not only on the characteristics of the personality (CRAIK, K.H. 1972), but also on the cultural and social conditions (LowENTHAL, D. and Prince, H.R. 1965; Bourassa, S.C. 1991; Müderrisoglu, H. and Gultekin, P.G. 2013; GunNARson, B. et al. 2017). Nevertheless, preferences change over time, including historical times (Bodenstein, E. 1972) and it is also recognised that aesthetic preferences influenced by the experience, knowledge and use of landscapes (KNudsen, D.C. et al. 1995; BodnáR, R.K. 2008; Parsons, G. and Carlson, A. 2008). An important aspect of our work was to evaluate the objective biophysical parameters of landscapes based on human perceptions somewhat combining the two approaches.

Our research was performed on two levels, based on human perceptions (questionnaires) and using a GIS approach to map the landscape values (i.e. the Land Cover Value, the Elevation Value and the Landscape Aesthetic Value) of Hungary. The separate discussion of land cover and elevation revealed the preferences of the two factors and the fact that their judgment is typically different. In addition, within the framework of CES, the connections between the landscape values and the offer of rural tourism on a national level, and in a region of landscape and tourist interest was also examined.

Most recently, a landscape value map based on the aggregation of thematic maps was prepared for the whole country in the National Atlas of Hungary (Csorba, P. et al. 2018). Compared to this work applying transmitter-side approach, the uniqueness of our methodology is the focus on human perceptions. In terms of outcomes, our subjective side research has led to spatially more homogeneous results, that is, in our landscape aesthetic value map there are higher proportion of less valuable areas and the perception of the elevation plays a dominant role. While in the case of the map based on an objective GIS based approach found in the National Atlas of Hungary besides mountainous and hilly areas lowlands (e.g. the Hortobágy) and the surroundings of larger lakes and some rivers can be found among the most valuable areas, in our map only mountainous and hilly areas proved to be extremely valuable. However, we emphasize that our statistical sample was consisted of Hungarian respondents; i.e. the map reflects only a limited group and do not take into consideration the viewpoints of foreign nationalities (e.g. those of arriving from mountainous areas seeking flat landscapes such Hortobágy). According to our understanding, general maps do not exist as all groups of people have different sense of taste.

As today's Danube Bend region is a relatively new formation, its current territory has not been studied in the context of landscape aesthetics or its relation to tourism. Previously, there were landscape aesthetic studies related to recreational potential, but they could concentrate on only a part of the current area, as at that time the Danube Bend was demarcated on a different territorial basis as a priority resort area. These studies still needed modern GIS-based solutions, and were largely based on raster evaluations of objective, physical landscape factors.

Considering the differences between Hungary and the Danube Bend region, we pointed to the fact that beside the larger values of TopoV, LCV was also higher, which is important because it reflects that the resulting map is not only the straight consequence of the larger relief but the land cover was also important. Mountains are not necessarily had large LAV, both conditions of the relief and the land cover had to be fulfilled to reach rank in the best category.

As observed by Walz, U. and Stein, C. (2018) the particularly and very attractive landscapes are primarily also destinations for nature-based tourism. Knowing the role of scenery in tourism, it can reasonably be assumed that the aesthetic and recreational values of the landscape are not independent of each other and largely overlaps in space. However, Casado-Arzuaga, I. et al. (2014) in their study on the Bilbao Metropolitan Greenbelt based on the data of public participation processes, found that the most important areas for recreation do not coincide with landscapes of the highest aesthetic val- 
ue. In another research SмIтH, M. and RAM, Y. (2016) studying the benefits of landscapes for visitors and tourists in 8 countries and 6 different kinds of landscape through a questionnaire survey came to the conclusion that visited landscapes had a passive characteristic and that the enjoyment of recreational activities has shown a negative correlation with other landscape functions, including aesthetics. Although the scale of the study area is different, according to our research, there is only a partial territorial overlap between the recreational function and the landscape aesthetic value, especially in the case of traditional mountain resorts and Lake Balaton.

The relatively few studies on landscape aesthetics and tourism work primarily with territorial and, only to a lesser extent, with product level analysis. There is even less research that focuses on a particular tourist product in connection with the assessment of landscape aesthetics. In the context of ecosystem services, SwafField, S.R. and McWilliam, W.J. (2013) explain that further studies are needed on landscape conditions that positively influence the perception of aesthetic landscapes, and on their functional relationship with other services. In our research we chose to analyse a special product, i.e. rural tourism, in which the landscape and the scenery play an increasingly important role (KuLCSÁR, N. 2013; Lontai-SzILÁGYI, Zs. et al. 2017).

According to the results obtained based on the data on the number of bed-places in rural accommodation in 2017, both LCV, TopoV and LAV are higher where there is a rural accommodation offer, which is equally true for Hungary and the Danube Bend region. In both cases, however, the effect of the relief is lower than that of the other two indices. Therefore, the effect of the topography on the offer of rural tourism is not primary. At the same time, in the case of the Danube Bend, the stronger effects observed for all three indices support the rural tourism possibilities of the area based on landscape value, which is more concentrated than in the country in general.

However, it has to be noted that the sample used for the research is primarily represen- tative for people between 25 and 50 years old and had a BSc or MSc degree, as they filled the questionnaire in the highest proportion. In addition, our study did not take into account the artificial factors which could decrease the aesthetic value of the landscape (e.g. billboards, hypermarkets built on the outskirts, high-voltage lines, highways and the wind power plants).

\section{Conclusions}

Our primary research goal was to prepare a landscape aesthetic map of Hungary based on the receiver-side approach using GIS. In order to reveal more detailed relationships, the two components of landscape aesthetic value, i.e. land cover and elevation values were also evaluated and mapped for Hungary. Then, to validate our landscape value maps we examined the connection between the presence of rural accommodation and landscape values both in case of Hungary and the Danube Bend region, which is a diverse and prominent area in its landscape, relief and tourism attractions.

Our results can be summarized as follows:

- In terms of Hungary, landscape aesthetic value based on human perception has produced spatially more homogeneous results compared to the assessment based on objective landscape factors and elevation played a more important role in the receiver-side evaluation. At the same time, in our view general landscape aesthetics map does not exists since every human being is different with diverse landscape preferences.

- The assessment of the Danube Bend region's landscape values pointed out that both elevation and land cover are decisive factors in landscape aesthetic value.

- Only a partial territorial overlap was found between the recreational function and the landscape aesthetic value and the most decisive landscape factors of the common areas are the elevation, the land cover and the larger water surfaces. 
- Nonetheless, the aesthetic value of the landscape and tourism are not independent of each other, as according to our product level analysis both LCV, TopoV and LAV were higher where there was a rural accommodation offer.

- Although there is no primary correlation between the offer of rural tourism and the relief, we found that in the Danube Bend region the stronger effects observed for LCV, TopoV and LAV indices support rural tourism developments.

\section{REFERENCES}

Adamowicz, W.L., Naidoo, R., Nelson, E., Polasky, S. and ZHANG, J. 2011. Nature-based tourism and recreation. In Natural Capital: Theory and Practice of Mapping Ecosystem Services. Eds.: Kareiva, P., Daily, G., Ricketts, T., Tallis, H. and Polasky, S., New York, Oxford University Press, 188-205.

Andersson, E., Tengö, M., McPhearson, T. and Kremer, P. 2014. Cultural ecosystem services as a gateway for improving urban sustainability. Ecosystem Services 12. 165-168. Available at http:// dx.doi.org/10.1016/j.ecoser.2014.08.002

Aranzabal, I., Schmitz, M. and Pineda, F. 2009. Integrating landscape analysis and planning: A multi-scale approach for oriented management of tourist recreation. Environmental Management 44. (5): 938-951.

Arnberger, A. and Eder, R. 2011. Exploring the heterogeneity of rural landscape preferences: an image-based latent class approach. Landscape Research 36. (1): 19-40.

Aubert, A. 2008. Az urbanizációs folyamatok és a rekreációs életterek összefüggései Magyarországon (Relationships between urbanization processes and recreational living spaces in Hungary). In Tájkutatás - Tájökológia. Eds.: Csorba, P. and Fazekas, I., Debrecen, Meridián Alapítvány, 447-445.

BAJмócy, P. 2014. A szuburbanizáció két évtizede Magyarországon (Two decades of suburbanization in Hungary). Észak-Magyarországi Stratégiai Füzetek 11. (2): 6-17.

Baloglu, S., Pekcan, A. and Santos, J. 2004. The relationship between destination performance, overall satisfaction, and behavioral intention for distinct segments. Journal of Quality Assurance in Hospitality and Tourism 4. (3-4): 149-165.

BeréNYI, I. 2010. Adalék a társadalmi egyenlőtlenség és a kultúrtáj kapcsolatának értelmezéséhez (A contribution to understanding the relationship between social inequality and cultural landscapes).
In A területi kutatások csomópontjai. Eds.: BARTA, Gy., Beluszky, P., Földi, Zs. and Kovács, K., Pécs, MTA Regionális Kutatások Központja, 514-531.

Bodenstein, E. 1972. Der Wandel touristischer Landschaftsb ewertung seit Beginn des 18. Jh. am Beispiel des Harzes. Hannover, Forschungs- und Sitzungsberichte der Akademie für Raumforschung und Landesplanung 76. 21-32.

BodnáR, R.K. 2008. Gondolatok a tájkép turisták célterület-kiválasztását befolyásoló hatásáról (Thoughts on the influence of landscape on tourists' destination choice). In Tájkutatás - Tájökológia. Eds.: Csorba, P. and Fazekas, I., Debrecen, Meridián Alapítvány, 503-509.

Bourassa, S.C. 1991. The Aesthetics of Landscape. London, UK, Belhaven Press. Available at https:// doi.org/10.1177/030913259301700215

Büttner, Gy., Bíró, M., Kosztra, B., Maucha, G., Pataki, R. and Petrik, O. 2002. Construction of a large scale (1:50k) land cover database in Hungary. Budapest, GSDI6 „From Global to Local” Available at http:// www.gsdi. org/gsdiconf/gsdiconfproceedings/ gsdi-6/gsdi-6.php

Carneiro, M., Lima, J. and Silva, A. 2015. The relevance of landscape in the rural tourism experience: Identifying important elements of the rural landscape. Journal of Sustainable Tourism 23. (8-9): 1217-1235. Available at: https://doi.org/10.1080/09 669582.2015.1037840

Casado-Arzuaga, I., Onaindia, M., Madariaga, I. and Verburg, P.H. 2014. Mapping recreation and aesthetic value of ecosystems in the Bilbao Metropolitan Greenbelt (northern Spain) to support landscape planning. Landscape Ecology 29. 1393-1405. Available at http://dx.doi. org/10.1007/ s10980-013-9945-2

CofAs, E. 2014. Models for the statistical analysis of trends in rural tourism activity in Romania. International Journal of Academic Research in Environment and Geography 1. (2): 18-25.

Cohen, J. 1992. Statistical power analysis. Current Directions in Psychological Science 1. (3): 98-101.

Craik, K.H. 1972. Psychological factors in landscape appraisal. Environment and Behavior 4. 255-266.

Csemez, A. 1996. Tájtervezés-Tájrendezés (Landscape planning-Landscape restoration). Budapest, Mezőgazda Kiadó.

Csorba, P., Ádám, Sz., Bartos-Elekes, Zs., Bata, T., Bede-Fazekas, Á., Czúcz, B., Csima, P., Csüllög, G., Fodor, N., Frisnyák, S., Horváth, G., Illés, G., Kiss, G., Kocsis, K., Kollányi, L., Konkoly-Gyuró, É., Lepesi, N., Lóczy, D., Malatinszky, Á., Mezôsi, G., Mikesy, G., Molnár, Zs., PÁsztor, L., Somodi, I., Szegedi, S., Szilassi, P., Tamás, L., Tirászi, Á. and VAsvári, M. 2018. Landscapes. In National Atlas of Hungary. Natural environment. Eds.: Kocsis, K., Gercsák, G., Horváth, G., Keresztesi, Z. and NemerkéNYI, Zs., Budapest, Geographical Institute, 
Research Centre for Astronomy and Earth Sciences, Hungarian Academy of Sciences, 112-129.

Daniel, T.C., Muhar, A., Arnberger, A., Aznar, O., Boyd, J.W., Chan, K.M.A., Costanza, R., Elmovist, T., Flint, C.G., Gobster, P.H., GretRegamey, A., Lave, R., Muhar, S., Penker, M., Ribe, R.G., Schauppenlehner, T., Sikor, T., Soloviy, I., Spierenburg, M., TACZAnOwsKa, K., TAM, J. and Von DER DUNK, A. 2012. Contributions of cultural services to the ecosystem services agenda. Proceedings of the National Academy of Sciences of the United States of America 109. 8812-8819. Available at http://dx. doi.org/10.1073/pnas.1114773109

DÁvid, L. and SzILÁgYi, Zs. 2008. A turizmus és a sporttevékenységek által okozott morfológiai változások kutatásának új eredményei (New results of morphological changes caused by tourism and sport activities). In Tájkutatás - Tájökológia. Eds.: Csorba, P. and Fazekas, I., Debrecen, Meridián Alapítvány, 503-509.

DövénYI, Z. and Kovács, Z. 1999. A szuburbanizáció térbeni-társadalmi jellemzői Budapest környékén (Spatial and social features of suburbanisation around the city of Budapest). Földrajzi Értesíto" / Hungarian Geographical Bulletin 48. (1-2): 33-57.

EU-DEM Metadata. Available at https://www. eea.europa.eu/data-and-maps/data/copernicus-land-monitoring-service-eu-dem\#tab-metadata

Field, A., Miles, J. and Field, Z. 2012. Discovering Statistics Using R. Los Angeles-London-New DelhiSingapore-Washington DC, SAGE Publications.

Frank, S., Fürst, C., Koschke, L., Witt, A. and MaKeschin, F. 2013. Assessment of landscape aesthetics - Validation of a landscape metrics-based assessment by visual estimation of the scenic beauty. Ecological Indicators 32. 222-231. Available at http://dx.doi.org/10.1016/j.ecolind. 2013.03.026

Fry, G., Tveit, M.S., Ode, Å. and Velarde, M.D. 2009. The ecology of visual landscapes: exploring the conceptual common ground of visual and ecological landscape indicators. Ecological Indicators 9. 933-947. Available at http://dx.doi.org/10.1016/j. ecolind.2008.11.008

Gábris, Gy., Pécsi, M., Schweitzer, F. and Telbisz, T. 2018. Relief. In National Atlas of Hungary. Natural environment. Eds.: Kocsis, K., GercsáK, G., Horváth, G., Keresztesi, Z. and Nemerkényi, Zs., Budapest, Geographical Institute, Research Centre for Astronomy and Earth Sciences, Hungarian Academy of Sciences, 42-57.

Gallarza, G.M., Gil, S.I. and Calderón, G.H. 2002. Destination image. Towards a conceptual framework. Annals of Tourism Research 29. (1): 56-78.

Government Decree No 1550/2017 (18 August) on the definition of the Danube Bend priority tourism development area and the implementation of certain developments in the region. Available at https://netjogtar.hu
Government Decree No 239/2009 (20 October) on the detailed conditions for pursuing accommodation service activities, and on the system for issuing accommodation provider licences. Available at https://netjogtar.hu

Gunnarsson, B., Knez, I., Hedblom, M. and Ode SaG, $\AA$ A. 2017. Effects of biodiversity and environmentrelated attitude on perception of urban green space. Urban Ecosystems 20. 37-49. Available at http:// dx.doi.org/10.1007/s11252-016-0581-x

Guo, Z., ZHANG, L. and LI, Y. 2010. Increased dependence of humans on ecosystem services and biodiversity. PLoS One 5. Available at http://dx.doi. org/10.1371/journal.pone.0013113

Healy, R.G. 1994. The "Common Pool" problem in tourism landscape. Annals of Tourism Research 21. 596-611.

Hungarian Central Statistical Office 2019. Turizmusszatellitszámlák, 2015-2016 (Tourism satellite accounts, 2015-2016). Available at http://www. ksh.hu/docs/hun/xftp/idoszaki/turizmszatt/turizmszat15.pdf

Hungarian Tourism Agency 2017. National Tourism Development Strategy 2030. Available at https://mtu. gov.hu/documents/prod/mtu_strategia_2030.pdf

Józsa, E., FÁbIÁN, Sz. and Kovács, M. 2014. An evaluation of EU-DEM in comparison with ASTER GDEM, SRTM and contour-based DEMs over the Eastern Mecsek Mountains. Hungarian Geographical Bulletin 63. (4): 401-423. Doi: 10.15201/hungeobull.63.4.3

Kabacoff, R.I. 2011. $R$ in Action. Data analysis and graphics with $R$. Shelter Island, N.Y., Manning Publications.

Kavaratzis, M. and Ashworth, G. 2005. City branding: an effective assertion of identity or a transitory marketing trick? Tijdschrift voor economische en sociale geografie 96. (5): 506-514.

Knudsen, D.C., Metro-Roland, M.M., Soper, A.K. and Greer, C.E. 1995. Landscape, Tourism, and Meaning. Hampshire, Ashgate Publishing Ltd. Available at https://doi.org/10.1111/j.1745-5871.2010.00672.x

Kocsis, K. 2018. Hungary at a glance. In National Atlas of Hungary. Natural environment. Eds.: Kocsis, K., Gercsák, G., Horváth, G., Keresztesi, Z. and NemerkénYI, Zs., Budapest, Geographical Institute, Research Centre for Astronomy and Earth Sciences, Hungarian Academy of Sciences, 13-15.

Kollányi, L., Jombach, S., Filep-Kovács, K. and NAGY, G.G. 2012. Tájindikátorok alkalmazása a tájképvédelmi területek lehatárolására és a tájkarakter meghatározására (Applying landscape indicators to delimit protected areas of aesthetic landscapes and to define landscape character). In Fenntartható fejlődés, élhető régió, élhető települési táj 3. Eds.: Szenteleki, K. and Szilágyi, K., Budapest, Budapesti Corvinus Egyetem, 175-188.

Kulcsár, N. 2013. A magyar falusi turizmus újabb átalakulása (New transformation of Hungarian rural tourism). A Falu 27. (3): 5-17. 
Kumar, P. 2010. The Economics of Ecosystems and Biodiversity: Ecological and Economic Foundations. London, Earthscan.

Langemeyer, J., Calcagni, F. and Baró, F. 2018. Mapping the intangible: Using geo-located social media data to examine landscape aesthetics. Land Use Policy 77. 542-552.

LeE, S., JeAn, S. and KIM, D. 2011. The impact of tour quality and tourist satisfaction on tourist loyalty: the case of Chinese tourists in Korea. Tourism Management 32. (5): 1115-1124.

LEw, A.A. 1991. Scenic roads and rural development in the US. Tourism Recreation Research 16. (2): 23-30.

Lóczy, D. 2002. Tájértékelés, földértékelés (Landscape evaluation, land evaluation). Budapest-Pécs, Dialóg Campus Kiadó.

Lontai-Szilágyi, Zs., Michalkó, G. and Kiss, K. 2017. Falusi turizmus a nagyvárosok térségében (Rural tourism in metropolitan areas). In Változások és kihívások a turizmusban. Eds.: Szalóк, Cs. and Ретүкó, Cs., Budapest, Budapesti Gazdasági Egyetem, 20-35.

Lothian, A. 1999. Landscape and the philosophy of aesthetics: Is landscape quality inherent in the landscape or in the eye of the beholder? Landscape and Urban Planning 44. 177-198. Available at http:// dx.doi.org/10.1017/CBO9781107415324.004

Love, J. and MaIr, P. 2017. walrus: Robust Statistical Methods. R package version 1.0.1. Available at https:// CRAN.R-project.org/package=walrus

Lowenthal, D. and Prince, H.R. 1965. English landscape tastes. Geographical Review 55. 186-222.

Macagno, G., Nunes, P. and Loureiro, M. 2010. The influence of agriculture landscape on tourism flows: An application to Tuscany. Available at www.ucl. ac.uk/bioecon/12th_2010/Macagno.pdf (Accessed 30.11.2010)

Martonné Erdős, K. 1990. Az egyéni rekreáció lehetőségei és megvalósulása Miskolc környékén (Possibilities and realization of individual recreation in the area of Miskolc). Doctoral Dissertation, Debrecen, Kossuth Lajos University.

Michalkó, G. 2008. A táj idegenforgalmi vonatkozású reflexiója (Tourism reflection of landscapes). In Tájkutatás - Tájökológia. Eds.: Csorba, P. and FazeKas, I., Debrecen, Meridián Alapítvány, 471-477.

Michalkó, G. 2012. A turizmus szerepe a vidék boldogulásában, a vidékiek boldogságában (The role of tourism in the prosperity of the countryside in the happiness of rural people). In A turizmus területi dimenziói. Ed.: Hanusz, Á., Nyíregyháza, Nyíregyházi Főiskola Természettudományi és Informatikai Kar, Turizmus és Földrajztudományi Intézet, 111-119.

Milcu, A.I., Hanspach, J., Abson, D. and Fischer, J. 2013. Cultural ecosystem services: a literature review and prospects for future research. Ecology and Society 18. (3): 44. Available at http://dx.doi.org/10.5751/ ES-05790-180344
Millennium Ecosystem Assessment 2005. Ecosystem and Human Well-being: Synthesis. Washington, D.C., Island Press.

Müderrisoglu, H. and Gultekin, P.G. 2013. Understanding the children's perception and preferences on nature-based outdoor landscape. Indoor and Built Environment 24. 340-354. Available at http://dx.doi. org/10.1177/1420326X13509393

MúgicA, M. and De Lucio, J.V. 1996. The role of onsite experience on landscape preferences. A case study at Doñana National Park (Spain). Journal of Environmental Management 47. (3): 229-239.

Oteros-Rozas, E., Martín-López, B., Fagerholm, N., Bieling, C. and Plieninger, T. 2018. Ecosystem services and landscape features across five European sites. Ecological Indicators 94. (2): 74-86. Available at http://dx.doi.org/10.1016/j.ecolind.2017.02.009

PAge, S. and Connel, J. 2010. Leisure - An Introduction. Harlow, Pearson Education Ltd.

Parsons, G. and Carlson, A. 2008. Functional Beauty. Oxford, UK, Oxford University Press.

Pérez, J.G. 2002. Ascertaining landscape perceptions and preferences with pair-wise photographs: Planning rural tourism in Extremadura, Spain. Landscape Research 27. (3): 297-308.

Plieninger, T., Dijks, S., Oteros-Rozas, E. and Bieling, C. 2013. Assessing, mapping and quantifying cultural ecosystem services at community level. Land Use Policy 33. 118-129.

Puczkó, L. and Rátz, T. 2006. Product development and diversification in Hungary. In Tourism in the new Europe: The challenges and opportunities of EU enlargement. Eds.: Hall, D., SMith, M. and MarciszewsKA, B., Wallingford, CABI, 116-126.

Puczkó, L. and Rátz, T. 2011. Az attrakciótól az élményig (From attractions to experiences). Budapest, Akadémiai Kiadó.

R Core Team 2018. R: A language and environment for statistical computing. Vienna, R Foundation for Statistical Computing. Available at https://www.R-project.org/ (Accessed 25.08.2018).

RенÁк, G. 2011. Turizmuspolitika Magyarországon (Tourism policy in Hungary). PhD Dissertation, Debrecen, University of Debrecen.

Rétvári, L. (ed.) 1986. A Pilis-Visegrádi-hegység környezetminősitése (Environmental assessment of the Pilis-Visegrád Mountains). Budapest, MTA Földrajztudományi Kutatóintézet.

Rogge, E., Nevens, F. and Gulinck, H. 2007. Perception of rural landscapes in Flanders: Looking beyond aesthetics. Landscape and Urban Planning 47. 159-174.

SAUNDERS, F.P. 2012. Seeing and doing conservation differently. Environmental Development 22.3-24. Available at http://dx.doi.org/10.1177/1070496512459960

Sмiтh, M. and RAM, Y. 2016. Tourism, landscapes and cultural ecosystem services: a new research tool. Tourism Recreation Research 42. (1): 113-119. Doi: 10.1080/02508281.2016.1253206 
Smith, M., Sulyok, J., Jancsik, A., Puczkó, L., Kiss, K., Sziva, I., PApp-VÁry, Á.F. and Michalkó, G. 2018. Nomen est omen - Tourist image of the Balkans. Hungarian Geographical Bulletin 67. (2): 173-188.

Somogyi, S. 1987. Magyarország természeti adottságainak idegenforgalmi szempontú értékelése (Tourism evaluation of Hungary's physical geography). Budapest, MTA Földrajztudományi Kutatóintézet.

Spiegler, P. 2011. A turisztikai imázselemzés. Turisztikai "tér-képek” a Dél-Dunántúlról. (Tourism image analysis. Tourism "spatial images" from Southern Transdanubia). PhD Dissertation, Pécs, University of Pécs.

Surová, D. and Pinto Correia, T. 2008. Landscape preferences in the cork oak Montado region of Alentejo, southern Portugal: Searching for valuable landscape characteristics for different user groups. Landscape Research 33. (3): 311-330.

SwAFField, S.R. and McWilliam, W.J. 2013. Landscape aesthetic experience and ecosystem services. In Ecosystem Services in New Zealand - Conditions and Trends. Ed.: Dymond, J.R., Lincoln, New Zealand, Manaaki Whenua Press, 349-362.

Szabó, G., SINGH, S.K. and Szabó, Sz. 2015. Slope angle and aspect as influencing factors on the accuracy of the SRTM and the ASTER GDEM databases. Physics and Chemistry of the Earth 83-84. 137-145. Doi: $10.1016 \% 2 F j . p c e .2015 .06 .003$

Szalai, K. and Hinek, M. 2013. Tájkép és turizmus kapcsolata, azaz milyen a szép táj, amely utazásra ösztönöz bennünket a XXI. században? (The relationship between landscape and tourism, that is, what is the beautiful landscape that inspires us to travel in the $21^{\text {st }}$ century?). In Jó(l)ét és turizmus: utazók, termékek és desztinációk a boldogság és a boldogulás kontextusában. Eds.: Michalkó, G. and RÁTz, T., Székesfehérvár-Budapest, Kodolányi János Főiskola - MTA CSFK Földrajztudományi Intézet - Magyar Földrajzi Társaság, 21-34.

Szalai, K. and Szilágyi, Zs. 2007. A táj a turizmus fókuszában (Landscape with focus on tourism). Földrajzi Közlemények 131. (55): 147-156.

Szilassi, P., Bata, T., Szabó, Sz., Czúcz, B., Molnár, Zs. and Mezósı, G. 2017. The link between landscape pattern and vegetation naturalness on a regional scale. Ecological Indicators 81. 252-259. Doi: 10.1016/j.ecolind.2017.06.003
Tardy, J., Schmidt, A., Csepregi, I. and Zsembery, Z. 2018. Nature conservation. In National Atlas of Hungary. Natural environment. Eds.: Kocsis, K., Gercsák, G., Horváth, G., Keresztesi, Z. and NemerkéNYI, Zs., Budapest, Geographical Institute, Research Centre for Astronomy and Earth Sciences, Hungarian Academy of Sciences, 144-155.

Todd, C. 2009. Nature, beauty and tourism. In Philosophical Issue in Tourism. Ed.: Tribe, J., Bristol, UK, 154-170.

Tribot, A.-S., Deter, J. and Mouquet, N. 2018. Integrating the aesthetic value of landscapes and biological diversity. Proceedings of the Royal Society B: Biological Sciences 285. (1886): 1-10.

Ungaro, F., Häfner, K., Zasada, I. and Piorr, A. 2016. Mapping cultural ecosystem services: connecting visual landscape quality to cost estimations for enhanced services provision. Land Use Policy 54. 399-412. Available at http://dx.doi.org/10.1016/j. landusepol.2016.02. 007

Vallés-Plannels, M., Galiana, F. and Van Eetvelde, V. 2014. A classification of landscape services to support local landscape planning. Ecology and Society 19. (1). 44-44. Doi: 10.5751/ES-06251-190144

Varga, Gy., Alföldi, L., Gábris, Gy., Horváth, G., Kocsis, K., Lázár, I., Maginecz, J., Szalai, J. and Szalay, M. 2018. Waters. In National Atlas of Hungary. Natural environment. Eds.: Kocsis, K., Gercsák, G., Horváth, G., Keresztesi, Z. and NemerkéNYI, Zs., Budapest, Geographical Institute, Research Centre for Astronomy and Earth Sciences, Hungarian Academy of Sciences, 70-81.

WAlz, U. and Stein, C. 2018. Indicator for a monitoring of German's landscape attractiveness. Ecological Indicators 94. 64-73.

WANG, Y., XIA, Z. and Chen, W. 2008. Aesthetic values in sustainable tourism development: A case study in Zhangjiajie National Park of Wuling Yuan, China. Journal of China Tourism Research 4. (2): 205-218. Doi: 10.1080/19388160802313837

Willis, C. 2015. The contribution of cultural ecosystem services to understanding the tourism-naturewellbeing nexus. Journal of Outdoor Recreation and Tourism 10. 38-43. 
